\section{BOT (BUILD-OPERATE- TRANSFER) PROJECTS AS A SUCCESSFUL MODEL OF PUBLIC-PRIVATE PARTNERSHIP}

\section{INTRODUCTION}

In the era of globalization, the world is becoming a huge market - a place, in which investors are constantly looking for opportunities for profitable investments. They carefully examine the determinants of the investment environment and target markets where appropriate legislation is in place and where realistic minimum rates of return are met by capital needs. The strategic orientation of serious investors motivates them to build lasting relationships with the participants in the economic and political life of the countries where they invest their capital. At the same time, many governments around the world are suffering from lack of financial resources to carry out large-scale projects related to the construction and modernization of infrastructure. The complex dilemmas of implementing public projects related to their economic efficiency and social function are finding their solutions. Governments are gradually realizing that most of the public services can be provided by the private sector more efficiently, faster and better $(33,300)$. Cooperation between the state and the private sector at this stage is a viable alternative that helps solve the problems of infrastructure, industry, environment, tourism, etc. $(25,16),(21$, 40-45). One of the most commonly used models of public private partnership (PPP), is the BOT (build-operate-transfer) formula, which opens up new opportunities and perspectives for both - governments and private investors (7). It contains enormous potential, which is widely known and

\section{SUMMARY}

Key words: BOT projects, buildoperate-transfer, concessions, project finance, infrastructure.

The paper examines the BOT (build-operate-transfer) projects as a viable model of publicprivate partnership. Its purpose is to reveal their conceptual framework, evolution, modern interpretations and implementation benefits. In view of the current economic realities of global financial deficit there are budget constraints at all levels of government in every country. The BOT projects can be considered as an alternative strategy for solving the financial and social problems of each government. They are a popular instrument of modernizing the transport infrastructure, energy sector, telecommunications, water supply, preserving of environment, etc.

\footnotetext{
Antoaneta Vasileva, redovni profesor, Fakultetu za međunarodnu ekonomiju i politiku Univerziteta za nacionalnu i svetsku ekonomiju u Sofiji. E mail: a.vasileva@unwe.bg.

Svetlana Ignjatijveć, vanredni profesor, Fakultet za ekonomiju i inženjerski menadžment, Univerzitet Privredna akademija u Novom Sadu. E mail: ceca@fimek.edu.rs.
} 
used successfully by many countries in the world in the fields of transport, energy, water supply, telecommunications and many social spheres.

The rich international practice is full of successful and unsuccessful examples of projects implemented under the BOT scheme. Will this concept stand the test of time? Will it meet the expectations of investors, governments and the public? One can hardly give an unambiguous answer to such questions, but lessons can be learned from the trial and errors of those who apply it $(9,79-84),(39,90-98)$. The experience of the countries that have more success in attracting foreign investment through BOT arrangements must be carefully analyzed and utilized.

The aim of this paper is to reveal the BOT projects as a viable formula of public-private partnership. To achieve this goal several broad objectives are pursued: to describe the conceptual framework of the BOT projects, to analyze the evo-

The rich international practice is full of successful and unsuccessful examples of projects implemented under the BOT scheme. lution of the concept and its modern interpretations, to discusses the models of BOT projects and to investigate the pros and cons in applying them on the basis of some best practices. Lessons learned from the rich international experience would be useful in implementing these flexible schemes in building public infrastructure by mobilizing private sector sources and providing so-called 'social infrastructure' that cannot be funded by the state. The conclusion outlines recommendations to strengthen the relevant implementation of the BOT arrangements.

The methodology of the paper is based on a desk research and case studies. An in-depth literature review has been conducted on the BOT concept in order to determine it as a successful model of public-private partnership and a key challenge of building the infrastructure. The data for the qualitative analysis are taken from government documents, BOT guidelines of UNIDO and the World Bank, research studies, scientific journals and other secondary sources to generate a comprehensive idea of these interesting schemes. Some terms and concepts are considered to be known to the scientific and business community and governmental institutions, so the theoretical discussions are deliberately limited.

Case studies of the Suez Canal (19,1-28), (13,182-203), the Channel Tunnel between France and the UK (3), the airport terminals in Turkey (1) as well as examples of good practices, such as the Greenway highway in the US, tunnels in Hong Kong, bridges in Great Britain, water supply systems in Turkey, Sydney Harbour, an airport in Toronto and statistics on many other sites worldwide have been used (6,45-58), (2,273$278)$, (32,61-69). A realistic, practically oriented approach has been applied, the purpose of which is to outline the economic and managerial aspects of the BOT projects. 


\section{CONCEPTUAL FRAMEWORK OFTHE BOT PROJECTS}

According to the UNIDO BOT Guidelines (1996) the essence of the formula BOT consists of the following: a government of a country grants a concession or license to a private investor company, giving it the right to construct and operate a facility for a specified period of time, sufficient to recover the investment and provide the planned profit, after which the asset is transferred to the state (see Figure 1).

The facility is most often a toll road, a bridge, a tunnel, a power plant, an oil refinery, a pipeline, an airport, a port, etc. The sites are mainly in the field of infrastructure, incl. telecommunications. Contractors are usually large companies, consortia of construction companies, consulting firms, financial houses and local partners or joint ventures. Once the site is completed, it is operated by the consortium formed, or most often by another company called an operator, for a certain time. Income from the operation is used to repay the allocated target loans, payment obligations for the maintenance of facilities and separating a reasonable profit for investors. What distinguishes this type of investment projects from the rest, is the presence of two pillars - a concession as a legal ground and project finance as economic foundation (17,604-616). Choosing a financial scheme and optimizing it, is of key importance to the viability of the transaction $(27,379-400),(38,90-98)$.

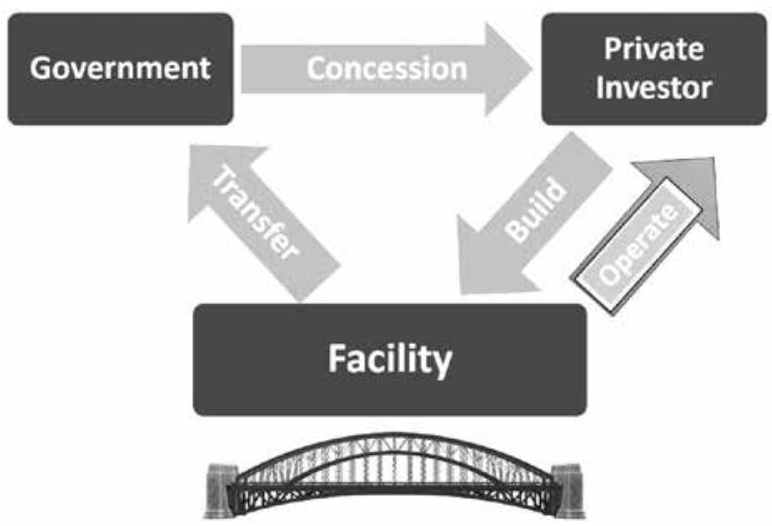

Figure 1. Scheme of the BOT project

Project finance relies on the revenue and profit that will be earned after the project is finished. In terms of funding, the B.O.T. projects are defined as an economic concept for completed facilities in a particular area of sufficiently high rate of return, implemented and operationally managed, usually by a legally independent or newly registered project company or 
company specifically created for the purpose of project implementation $(25,8)$, the so called special purpose vehicle (SPV). The decision to finance such an investment project is based on the expectation that it will generate a volume of cash flows, enough to pay at least the operating expenses and the loan servicing obligations. The main difference between the limited recourse financing from the ordinary credit is that the guarantee for the repayment of the debt to the creditors is not the financial resources and internal reserves of the borrowers or affiliates of these borrowing companies, but the future cash flows from the operation of the project and the perfect contractual frame (25,40-53).

The concession is usually granted for a period of 15-30 years, depending on the nature of the project and the legal regulations of the individual country. In the case of the Channel Tunnel and the Suez Canal for example, the term of the concession is 55 and 99 years $(13,182-2013)$. After this pre-arranged period the ownership of the facility (or the right to use it, depending on the legislation) is transferred again to the government (25,7-8). Since investors receive financing mainly from private sources, the BOT projects are obviously a good alternative to increasing the financial instruments of any government.

However, there is also an option where not a concession is allowed but a building and operating permit (license or franchise) is granted. Such an approach is applied when facilities which are not considered to be public property can be used or the state does not exercise its sovereign rights on them. Activities related to the construction of such projects should not be a state monopoly. There are other property rights - easements, which are also relevant to the problems of BOT projects. In most countries there is a lack of comprehensive analysis about them.

It is interesting to note that such a formula is often used in the field of tourism, in the construction and operation of tourist complexes and amusement or natural parks (France, Mexico, South Africa), of prisons (UK, Germany), hospitals (Germany), housing (Nigeria), urban revitalization (Netherlands), etc. $(23,1865-1880),(25,12-15),(39,1097-1101)$. In Spain, a similar approach is used in the construction of garages and parking places in central urban areas, as well as in the operation of holiday beaches (5,1-16), (17,604-616).

Experience has shown that choosing one of these alternatives is fraught with many financial and legal difficulties $(25,190-$ 194). It is not easy to foresee the realities in terms of property, legal regime, even the integrity of the state after the end of the concession period. 


\section{Evolution of the concept BOT}

The acronym BOT was used for the first time by the Turkish Prime Minister Turgut Ozal in the 1980s for the construction of large power plants and immediately entered in circulation as a term in the economic literature $(18 ; 24)$. The abbreviation in English has gained popularity all over the world. The concept 'build - operate - transfer' has been used with success by the Hong Kong authorities since the late 1960s (6, 45-58), but it was firmly established in the 1980s and was actively applied in Malaysia and the Philippines in the mid-decade, and later in China, India, Indonesia, Thailand, Bangladesh, Mexico, Chile, Venezuela, Argentina, Nigeria, Kenia and more (32,61-69). Countries such as Vietnam, Korea, China, Turkey, etc., have specific legislation for BOT projects. The USA and the UK have the practice of adopting a specific law for each project. For example, in order to start denationalization in rail transport in the UK, the owner of the British Railways and United Railway Lines Ltd asked the Parliament to pass a law and in 1995, the so-called Hybrid Bill was adopted. It is called the Hybrid Bill because it combines the legal norms required by both the public and private sectors $(37,10)$.

In most countries the application of BOT projects is governed by a set of regulatory documents, the most important of which are the current laws on foreign investment and concessions (35). Hungary and Poland have made significant progress in implementing this useful mechanism, notably in the construction of highways. Russia, Czech Republic, Bulgaria, Serbia, Macedonia, Albania, Croatia and Romania are also looking for ways to use it $(8,19-222)$.

Although the term 'build-operate-transfer' is relatively new, in practice it is not. In Europe, such projects have long been called "concession" projects and big corporations have worked in many countries in the construction of numerous infrastructure projects $(30 ; 7)$. However, not all concession projects are related to construction, much less to cooperation between the state and the private sector. Using the formula B.O.T. (build-operate-transfer), the government practically effectively protects state interests. It authorizes a private company or consortium to prepare, finance, construct and operate the project for a fixed period, called a concession period. Concessionaires assume responsibility for the completion of the project, as well as all risks associated with construction and control of the invested funds $(22,407-417)$. Costs incurred by them are reimbursed from the collection of revenues after the completion of the project and its commissioning. After the concession period ends, the contract can be renewed at the choice of the government or the right of transfer of the facility by the concessionaire to a government 
authority, in rare cases to another private company or local administration.

The BOT projects have a complex organizational and management structure (11), (33,316-125). It is directly dependent on the financing scheme that the investors choose. Specific approaches and procurement procedures, such as tenders, negotiations, etc., which are regulated by law, are applied in the selection of participants $(26,91-97)$. There are different relationships between the participants, which are manifested during the technological cycle - preparation, conclusion of contracts and realization of the transactions $(23,1-7)$. This process implies a unique system of contracts and agreements with a diverse range of activities, which often have their own dynamics and require competent management (7).

The first project built according to the B.O.T. concept in the modern world is the Suez Canal linking the Mediterranean and the Red Sea (19), (13,182-203). The channel, called the Suez Canal, was the world's first international initiative of this magnitude in the 19th century. In 1855 the Frenchman Ferdinand de Lesseps was tasked to form a company to construct and operate the Suez Canal. Thus, the Compagnie Universelle du Canal Maritime de Suez, created by him, concluded a concession agreement with the Egyptian government for a period of 99 years. The land was donated by the Egyptian government, which greatly reduced taxes on imported materials and facilities for the construction of the site. The company was required to pay all costs for design and construction. The route of the highway had to be built in consultation with King Muhammad Ali. The Egyptian government agreed to receive 15\% of the company's annual revenue from the operation of the channel, $10 \%$ should go to shareholders and $75 \%$ - to the company but $80 \%$ of the people working on the construction and operation of the site should be Egyptian citizens. The King of Egypt accumulated a great deal of debt in financing the site. In 1875 the liabilities exceeded the gross domestic product of the country. As a result, he decided to sell his 30\% stake. The government of England bought the shares of the King of Egypt, and shortly after, the shares of Ferdinand de Lesseps. Although the cost of the Suez Canal at the end of ten years of construction amounted to USD 18 million, it proved to be a good deal. Already in the first decade of the 20th century, UK investment increased tenfold.

Undoubtedly, the most remarkable project of the 20th century, implemented under the scheme of BOT, is the Channel Tunnel under la Manche (30), (10), (3). The idea of a short cut through the strait has a long history - it dates back to Napoleon's time, but it has not been realized until 1994. This grand private-equity initiative amounts to more than USD 21 billion, 
well over its predicted budget and is a subject of constant debate. Nevertheless, it is impressive in terms of technical achievement and is a classic example of a large-scale project that brought together many participants - two governments, more than a hundred of solid banks, a dozen reputable construction companies, research groups, consultants and many other institutions, each one of which has different functions. The framework of contracts accompanying the construction and operation of the facility is extremely complex. It is characterized by its implementation on several levels. First, an international treaty between the United Kingdom and France, known as The Treaty of Canterbury, was ratified, reflecting the willingness of both parties to contribute to the development of the project. In the next phase, laws have been passed by which governments grant the private sector a 55-year concession and only then all other contracts have been concluded. They, as well as the financing of the project, are of great interest from economic and legal point of view and have been studied all over the world.

Of course, there are other interesting projects in which the BOT mechanism is implemented. It should not be thought that this approach is particularly applied to megaprojects only, it is also used in the construction of facilities of a more modest scale (7). The model BOT is widely used in the construction of toll highways and road sections in the United States (Dallas-Greenway Highway in Virginia, Conway in

BOT approach is applied not to megaprojects only, it is also used in the construction of facilities of a more modest scale South Carolina, etc.), bridges in England (the bridge to Sky Island, the bridge connecting England and Wales, the Queen Elizabeth and Dartford Crossing bridges over the River Thames, etc.), bridges, power plants and water supply systems in Turkey, waste treatment plants in Australia, India, Morocco, UK and the USA, telecommunications satellites in Italy and countries of South America, railways in Kenya and more (15, 145-166), (26,91-97), (25, 12-15). To the question 'Where can the B.O.T. concept be applied?', the one-word answer is: 'Worldwide'.

\section{Models of BOT projects}

The BOT scheme also operates by other formulas (11), each of which provides an extremely wide-ranging field of action for private investors, providing significant revenue to the state while safeguarding its interests. Similar formulas are:

- BOOT (build - own - operate - transfer). Careful examination of this scheme shows that the government again gives a private sector investor a concession to build a facility, acquire ownership of it, operate it and, at the end of the concession period, transfer it back to the state. This modification is different from the main formula BOT in the element of ownership, but in many cases, there is no 
difference in practice, especially if the legislation allows the concessionaire to acquire ownership of the object constructed by him $(26,91-97)$. A typical example of a BOOT type project is the paid bridge over the River Thames - Dartford Crossing. The concessionaire is given the right to collect not only the fees from the bridge but also from the adjacent tunnels for the purpose of reinvestment in new construction.

- BOO (build - own - operate). The point is the following: the investor designs, finances, constructs and operates the site, but after the termination of the contract does not transfer it, and becomes the owner of all or part of the capital. In this way, he retains ownership of the site and can manage it indefinitely while continuing to generate revenue from it. This scheme is beneficial for private investors but not acceptable to the government. It is not particularly flexible and is not often use $(17,604-616)$.

- DBFO (design - build - finance - operate). This approach is widely used in the construction of highways and roads in the UK and the USA. Too often, traveling on these roads is free. Investors are paid "shadow tolls" by the government. The number of passing cars is detected by radar or other sensitive electronic devices and the state assumes the fee for each car. This method guarantees a return on investment since travelers do not avoid highways and do not seek free roads and highways (31,5-25).

- BLT (build - lease - transfer) or BRT (build - rent - transfer). The private investor finances, designs and constructs a facility while retaining ownership of it. For certain time he may lease it to another operator. A similar rental approach BRT was used by Hong Kong-based Standard Chartered Bank, which renovated a downtown building renting it for 25 years to the Japanese construction company Nishimatsu Property. The Japanese company reconstructed the building and after the expiration of the agreed term returned $70 \%$ of it to the bank, leaving $30 \%$ for itself and using them as a commercial area $(16,424-433),(20,6-11)$.

- LROT (lease - renovate - operate - transfer). This method can be illustrated with one example from the practice of Venezuela. The government of the country has leased the Minorca iron ore processing plant to a Japanese consortium involving Kobe Steel Ltd and some trading companies for 11 years. The consortium modernized the plant and introduced new production processes. It financed this operation with a loan from the International Finance Corporation (IFC) - a branch of the World Bank to pro- 
mote private sector activity - and from 11 Japanese banks. The Venezuelan state authorities guaranteed the supply of raw materials and assisted in overcoming some of the difficulties associated with obtaining licenses and more. Once the lease was over, the Venezuelan government could receive the refurbished plant for free (7), (25,10-12).

- BTO (build - transfer - operate). This model involves the financing and construction of a facility such as a power plant or water supply system by the state that entitles the private sector to operate and maintain it. It is mostly used in France (where it is called Affermage) and also in Central and Eastern European countries. Hong Kong's first chemical waste treatment plant was managed and operated in this way. The government retained ownership of it but allowed a private consortium to operate it. The consortium obtained this right based on a franchise agreement with a term of 15 years (32,61-69).

International practice undoubtedly shows plenty of different models. Taking into account the nuances of the derivative formulas it can be noted that they follow a stable algorithm that is repeated basically. This proves their applicability to any change in the dynamic business environment and further increases the interest in these flexible schemes.

\section{PURPOSES FOR IMPLEMENTING THE BOT MODEL}

The BOT deals are not only associated with the construction, modernization and maintenance of infrastructure, they are an effective mechanism for attracting foreign investment and developing the capital market. The magnitude of their application is most significant in advanced market economies and countries in the region of Southeast Asia (2,273-298). BOT is a very effective mechanism They are a worked-out formula for solving some of the for attracting foreign investment problems of transition to a market economy and are of and developing the capital market. interest to the countries of Central, Eastern and SouthEastern Europe. Especially Turkey is often cited as an example of successful implementation of investment projects under the BOT scheme, (e.g. energy systems, water supply facilities, bridges, airport terminals, etc.) building the legal foundation for their active application. 'The legal framework of the BOT model has been determined by the law in 1994 in Turkey. The law gives the possibility that capital stock companies or foreign companies are commissioned in the framework of the BOT model in terms of the construction, operation and transfer of bridges, tunnels, barrages, watering, drinking and potable water, clarifying plants, drainage, communication, energy production, 
conveyance, distribution, minerals and their operations, factories and similar plants, investments preventing environmental pollution, motorways, railways, underground and aboveground parking garages and sea and air ports for civil use and similar investments and services.' as per Acar $(1,62)$. The model BOT may be a part of the privatization program of countries with developed market and emerging market economies (28,53-61), (27,379$400),(21,40-45)$. Preference for such privatization techniques is shown by the USA, Great Britain, Ireland, Hong Kong, India, Pakistan, Malaysia, Bangladesh, the Philippines and others.

The BOT projects have many advantages when applied after careful due diligence $(4,27-54)$, given the right conditions and with enough flexibility on the part of government institutions. Their positive dimensions are associated with the following effects $(9,69-84)$ :

- release of the state from the obligation to seek financial resources for construction and modernization of the infrastructure,

- reducing the need for tax increases as private investors manage and maintain the facilities during the concession period,

- reducing the bureaucracy and administration that has the authority to exercise control over construction and to manage projects until they are completed,

- profit as a major driver of private initiatives contributes to faster implementation of infrastructure projects,

- BOT projects facilitate the transfer of new technologies, management experience and know-how,

- although it is exposed to many risks and threats, the private sector is more able to deal with them than the bureaucratic public administration.

The horizon for analysis and evaluation would be expanded $(4,27-54)$ if the negative aspects of this modern model of investment decisions were also indicated, namely:

- they can provoke severe civil resistance, especially with the introduction of tolls on highways, bridges, tunnels and other services, which were in the past free of charge,

- projects may fail with inaccurate estimates and cost overruns. If this happens or the duration of an infrastructure project is extended, the government is forced to bear the costs of operation and maintenance, which means that public funds will be used,

- incentives that governments sometimes give investors in the form of tax preferences or subsidies may be more expensive for taxpayers.

The BOT projects are accompanied by serious dangers and risks $(28,53-61),(16,424-433),(9,69-84)$ at all stages of their de- 
velopment. Typical risks for this type of investment activity are political, (including country risks), financial, market-pricing, technical and environmental risks. They threaten both the participants and the government of the host country $(15,145-166)$, $(31,5-25)$. Effective risk management of macro and microenvironment is of great importance for the success of BOT projects. It implies a rational attitude towards them and a choice of an integrative type of strategy, i.e. teaming up and collaborating between all stakeholders to address potential risks and threats $(27,379-400)$. Developing an adequate mix of management approaches to counteract risk should be based on complex analysis, selection of appropriate strategy and use of appropriate techniques $(23,1-7))$.

The BOT projects are clearly a good solution of the problems of countries with financial shortages. In the conditions of transition to a market economy and the need for significant investments for the implementation of structural reforms, the attracting of foreign capital using the formula BOT is a real alternative, in much cases better than the traditional public procurement (14,56-74), (26,91-97).

The field of application of such flexible mechanisms in the field of infrastructure can be widened - for example in the construction of power plants, water supply systems, telecommunication facilities, etc. (36). In this sense, participation in the projects of the European Union (EU) to create a unified transport, telecommunications and energy network would contribute, on the one hand, to increase the flow of capital, and on the other, the integration with European structures. The EU projects that have been developed include the use of the BOT approach, which shows a desire for investment cooperation and an intention to mobilize private capital.

Opportunities and prospects for implementation of BOT projects are determined by the factors of the investment climate, which includes the legal aspects of state regulation, the state of the economy, the political conditions, the foreign trade regime, the tax and banking system, the privatization and last but not least, the investment culture $(29,127-138)$.

\section{CONCLUSION}

Greater pragmatism, flexibility and objectivity are needed in creating an enabling environment for more significant investment activity. Practice shows that BOT projects are successful where the government is involved and provides the necessary support $(21,40-45)$. It is not enough to just improve the individual elements of the investment climate, it is necessary to develop a 
comprehensive system of measures that includes incentives, restraints, guarantees and others, specifically concerning major infrastructure projects, including those under the BOT formula.

The analysis of the investment environment gives reason to claim that efforts should be made to improvement of legislation and regulatory mechanisms relevant to the BOT projects and refining the incentives and preferences for large investors in a separate regulation, maintaining stable macroeconomic indicators, political stability, further liberalization of the foreign trade regime and harmonization of foreign trade policy with European and regional standards, development of the banking system and the capital market, improving the tax system, rapid privatization, creation of marketing infrastructure of the projects with an established information network and institutional framework and change in the attitude of the business community and society towards investments, investors and investment projects $(2,273-298)$.

In this respect, the idea of establishing a regional network of centers for analysis and planning of infrastructure projects is essential. It can fill the current gap in terms of information deficit and adequate marketing structure of projects and lack of coordinated strategies in Southeast Europe. In addition, it would assist in reconciling national interests in the region in the construction of joint projects and in creating favorable conditions for the implementation of projects under the BOT scheme. It should be considered as a possible alternative in solving the problems of the state in the conditions of transition through public private partnership and in making a management decision to participate in an investment project.

Using the BOT mechanism can be considered a promising prospect. Not only will it boost the region's economic potential, it will also significantly foster the EU accession process. Society may need more time to reflect on this new type of projects and to recognize the institutional changes that accompany them.

\section{REFERENCES}

1. Acar, M, Turkish model: The build-operate-transfer model for aerodrome terminal buildings, Ankara, Directorate General of Civil Aviation, 2009.

2. Aerts, G, Grade, T, Dooms, M, Haezendonck, E, Public-Private Partnerships for the Provision of Port Infrastructure: An Explorative Multi-Actor Perspective on Critical Success Factors, The Asian Journal of Shipping and Logistics, Volume 30, Number 3, 2014.

3. Anderson, G, Roskrow, B, The Channel Tunnel Story, London, E \& F N Spon, 2007.

4. Boeva, B, Vassileva, A, Public - Private Partnerships: Formulae for Success, Incentives and Barriers, Vizione, N15, 2010. 
5. Boxmeer, Van B, Van Beckhoven, E, Public-Private Partnership in urban regeneration: a comparison of Dutch and Spanish PPPs. European Journal of Housing Policy, 5, 2005.

6. Cheung, E, Chan, A, Kajewski, S, Factors contributing to successful public private partnership projects: comparing Hong Kong with Australia and the United Kingdom, Journal of Facilities Management, 10(1), 2012.

7. Concessions, Build-operate-Transfer (BOT) and Design-Build-Operate (DBO) projects, 2012. Washington, D.C., World Bank, accessed at https://ppp.worldbank.org/public-private-partnership/agreements/ concessions-bots-dbos\#BOT_projects

8. COST Action TU1001 - 2013: Part I Country Profiles (2013). Discussion Papers on Public Private Partnerships in Transport: Trends \& Theory, Edited by Verhoest, K., et al, COST Office, Bari, 2013.

9. Ghazali, M, Rashid, S, Sadullah, A, The critical success factors for publicprivate partnership highway construction project in Malaysia, Journal of Engineering and Technology, Vol.8 No. 1, 2017.

10. Grimsey, D., Lewis, K, Public Private Partnerships: the worldwide revolution in infrastructure provision and project finance, Edward Elgar Publishing. 2007.

11. Guidelines for Infrastructure Development through Build-Operate-Transfer (BOT) Projects (UNIDO BOT GUIDELINES), UNIDO, Vienna, 1996.

12. Guidelines for Successful Public-Private Partnerships, European Commission, Brussels, 2003.

13. Hicks, G, Disraeli, Derby and the Suez Canal, 1875: Some Myths Reassessed, History, 97 (2 (326)), London, 2012.

14. Hoppe, E, Schmitz, P, Public-private partnerships versus traditional procurement: Innovation incentives and information gathering, The RAND Journal of Economics, 44 (1), 2013.

15. Hussein, N., Ndonye, H, Anyika, E., Gongera, G, Evaluation of PPP Strategies on Concession Performance: Case of Rift Valley Railways Concession, Kenya, European Journal of Business and Management, Vol.6, No.39, 2014.

16. Hwang, B-G., Zhao, X., Gay, M, Public private partnership projects in Singapore: Factors, critical risks and preferred risk allocation from the perspective of contractors, International Journal of Project Management, 31, 2013.

17. Irimia-Diéguez, A, Oliver-Alfonso, D, Models of Public-Private Partnerships in Megaprojects: the Spanish case, Organization, technology and management in construction, 4 (3), 2012.

18. Levy, S, Build, Operate, Transfer, New York, John Wiley \& Sons, New York, 1996.

19. Mahmood, F, History of the Suez Canal: Geo-political Aspects, Dissertation, Centre of West Asian Studies, Aligarh, 1997.

20. Malek, S, Akalkotkar, P, Driving Forces Leading to The Adoption of PPP - Perspectives from Gujarat (India), Hong Kong and Australian Practitioners, International Journal for Innovative Research in Science \& Technology, Volume 2, Issue 09, 06-11, 2016.

21. Mishra, B, Shah, M, Public Private Partnership in India: Pertinence, Performance and Potential, International Journal for Innovative Research in Science \& Technology, Volume 3, Issue 05, 2016.

22. Mudi, A, Quantity Surveyor's Role in Public-Private Partnership Highway Concession, International Journal of Engineering Research \& Technology (IJERT), Vol. 5 Issue 02, 2016.

23. Mudi, A., Kolawole, O, Yusuf, T, Udo, M, Effective Project Preparation Process: A Key Factor to a Successful PPP Infrastructure Development, International Journal of Engineering Science Invention, Volume 5, Issue 8, 2016.

23. Nijkamp, P, Van der Burch, M, Vindigni G, A Comparative Institutional Evaluation of Public Private Partnerships in Dutch Urban Land-use and Revitalization Projects, Urban Studies, 39(10), 2002. 
BOT (BUILD-OPERATETRANSFER/IZGRADIKORISTI-PREDAJ) PROJEKTI KAO USPEŠAN MODEL JAVNO-PRIVATNOG PARTNERSTVA

\section{REZIME}

Ključne reči: BOT projekti, izgradi-koristi-predaj, koncesije, finansiranje projekata, infrastruktura.

Rad proučava BOT (build-operate-transfer/izgradi-koristipredaj) projekte kao održiv model javno-privatnog partnerstva. Njegova svrha je da otkrije njihov konceptualni okvir, evoluciju, savremene interpretacije i koristi od primene. S obzirom na trenutne ekonomske realnosti globalnog finansijskog deficita, postoje proračunska ograničenja na svim nivoima vlasti u svakoj zemlji. Projekti BOT mogu se smatrati alternativnom strategijom za rešavanje finansijskih i socijalnih problema svake vlade. Oni su popularan instrument modernizacije saobraćajne infrastrukture, energetskog sektora, telekomunikacija, vodosnabdevanja, očuvanja životne sredine, itd.
24. Ozcan, I, Risk Management in Turkish BOT Transport Projects, Conference paper at the Transportation Research Board 93rd Annual Meeting, Washington, January 2014. accessed at https://trid.trb.org/ view/1288234

25. Public-Private Partnerships, Reference Guide, World Bank, Washington DC, 2017.

26. Rahman, I, Memon, A, Zulkiffli, N, PPP Procurement Methods in Malaysian Construction Industry, Journal of American Science, 10(7), 2014.

27. Reeves, E, Palcic, D, Flannery, D, PPP procurement in Ireland: an analysis of tendering periods, Local Government Studies, 41, 2015.

28. Qiao, L, Wang, S, Tiong, R, Chan, T, Framework for Critical Success Factors of BOT Projects in China. The Journal of Structured Finance, 7(1), 2001.

29. Qiu, L, Wang, S, BOT projects: Incentives and Efficiency, Journal of Development Economics, 94(1), 2011.

30. Sapte, D, Public Private Partnerships: BOT Techniques and Project Finance, Euromoney Books, London, 2006.

31. Sy, D, Likhitruangsilp, V, Onishi, M, Nguyen, P, Different perceptions of concern factors for strategic investment of the private sector in PPP transportation projects, ASEAN Engineering Journal Part C, Vol.5 No.2, 2016.

32. Ullah, A, An Analysis of Public Private Partnership (PPP) Policies in South Asia, International Journal of Humanities and Social Sciences, Volume 4, Number 1, 2014.

33. Vassileva, A, Međunarodni biznis - savremeni oblici i globalni izazovi, Beograd, Cenrtar za strateške prognoze, 2018.

34. Walker, S, Adrian, C, Privatized infrastructure: the build-operatetransfer approach. Thomas Telford, 1995.

35. Werneck, B, Saadi, M, The Public Private Partnership Law Review, Law Business Research Ltd, London, 2017.

36. World Bank Group Support to Public-Private Partnerships, EBRD/The World Bank, Washington DC, 2015.

37. Yong, H, Public-private Partnerships Policy and Practice: A Reference Guide, Commonwealth Secretariat, London 2010.

38. Zayyanu, M, Johar, F, Measuring the Success of Public-private Partnership Projects: a Conceptual Framework, Journal of Built Environment, Technology and Engineering, Vol. 2 (March), 2017.

39. Zayyanu, M, Johar, F, Coping with Challenges of Public-Private Partnership (PPP) for Housing Delivery in Nigeria, International Journal of Engineering and Technology, 7(2.29), 2018. 